\title{
Pemberdayaan Generasi Milenial Tourisme Dalam Festival Pacu Jalur Tradisional Kabupaten Kuantan Singingi
}

\author{
${ }^{1}$ Syafri Harto, ${ }^{2}$ Syofian \\ ${ }^{12}$ Program Studi Usaha Perjalanan Wisata, Universitas Riau \\ e-mail : syafriharto@lecturer.unri.ac.id
}

\begin{abstract}
Abstrak
Tujuan penelitian ini menggambarkan pemberdayaan generasi milenial dalam Festival Pacu Jalur Tradisional Kabupaten Kuantan Singingi. Peneliti tertarik melakukan penelitian karena keberhasilan Festival Pacu Jalur Tradisional Kabupaten Kuantan Singingi keberhasilan meraih penghargaan pariwisata terpopuler di Indonesia di Ajang Anugerah Pesona Indonesia. Metode penelitian yang digunakan menggunakan metode kualitatif dengan pendekatan studi kasus. Teknik pengumpulan data mengunakan wawancara, observasi dan dokumentasi. Metode pemilihan informan penelitian secara snow ball sampling dengan analisis data model interaktif. Hasil penelitian menunjukkan bahwa pemberdayaan generasi milenial dilakukan dengan pendekatan media sosial oleh pemerintah Kabupaten Kuantan Singingi. Selain itu faktor yang mempengaruhi adalah rasa kecintaan generasi milenial terhadap Festival Pacu Jalur Tradisional Kabupaten Kuantan Singingi. Faktor berikutnya rasa kecintaan para masayarakat asal Kabupaten Kuantan Singingi dan menanamkan rasa bangga kepada keturunannya akan Festival Pacu Jalur Tradisonal. Temuan penelitian selanjutnya media yang digunakan dalam menyebar luaskan informasi Festival Pacu Jalur melalui media sosial Facebook, Instagram, Youtube yang popular digunakan generasi milenial. Selain itu factor keterlibatan mahasiswa yang melakukan kegiatan pengabdian di Kabupaten Kuantan Singingi yang juga ikut berpartsipasi. Dari hasil penelitian ini dapat menjadi rujukan bagi peniliti berikutnya tentang pemberdayaan masyarakat pada Festival pariwisata lainnya.
\end{abstract}

Kata Kunci: Pacu Jalur, Pemberdayaan, Generasi Milenial, Media Sosial.

Abstract
The purpose of this research is to describe the empowerment of the millennial generation in the Kuantan Singingi Regency Traditional Pathway Festival. Researchers are interested in doing research because of the success of the Kuantan Singingi Regency Traditional Pathway Festival, the success of winning the most popular tourism award in Indonesia at the Anugerah Pesona Indonesia Event. The research method used is a qualitative method with a case study approach. Data collection techniques using interviews, observation and documentation. The method of selecting research informants using snow ball sampling with interactive model data analysis. The results showed that the empowerment of the millennial generation was carried out with a social media approach by the Kuantan Singingi Regency government. In addition, the influencing factor is the love of the millennial generation for the Kuantan Singingi Regency Traditional Pathway Festival. The next factor is the sense of love of the people from Kuantan Singingi Regency and instilling a sense of pride in their descendants of the Traditional Pathway Festival. The findings of further research are the media used in disseminating information on the Pacu Jalur Festival through social media Facebook, Instagram, Youtube which are popularly used by the millennial generation. In addition, the factor of student involvement who carries out community service activities in Kuantan Singingi Regency also participates. From the results of this study, it can be used as a reference for the next research on community empowerment at other tourism festivals.

Keywords: Pace Path, Empowerment, Millennial Generation, Social Media. 


\section{PENDAHULUAN}

Pemberdayaan merupakan bentuk kegiatan pemerintah dalam melibatkan masyarakat dalam proses pembangunan baik ekonomi, sosial, budaya, yang merupakan proses perkembangan dengan para digmapembangunan yang digaungkan oleh UNDP yang bersifat politis yang mengalihkan perhatian dunia dari akar masalah pembangunan berkelanjutan(Khandakar Qudrat-I Elahi, 2009) dan sebelumnya(Blunt, 1995)telah menemukan bahwa selesai system kolonial, negara maju membuat imperialism baru dengan konsep pembangunan manusia berkelanjutan dan tata kelola pemerintahan yang baik bagi negara-negara berkembang. Konsep ini juga dianut oleh Pemerintah Indonesia dan Pemerintahan Daerah. Pembangunan di Indonesia mengadopsi Sustainable Development Goals (SDGs) yang disebut dengan Integrasi Pembangunan Nasional dengan peninkatan peran koordinasi, melibatkan semua pihak, dan kelembagaan yang bias langsung bekerja (Pokok Arahan Presiden dalam Sidang Kabinet tanggal 23 Desember 2016). Berkaitan dengan integrasi pembangunan nasional pemerintah dan pemerintah daerah harus bias melakukan proses pemberdayaan masyarakat dalam pembangunan. Selain itu dalam meningkatkan pendapatan negara dan daerah pemerintah tidak hanya bergantung pada industry sumber daya alam namun dalam perkembangannya juga pada pembangunan manusia dan pariwisata.

Pacu Jalur merupakan potensi destinasi wisata yang dimiliki oleh Kabupaten Kuantan Singingi, pertunjukkan pacu jalur banyak mengunakan sumber daya manusia, terutama kaum laki-laki generasi Produktif. Selain itu berkaitan dengan sumber destinasi wisata, Pacu Jalur juga merupakan destinasian dalam Kabupaten Kuantan Singingibahkan Provinsi Riau. Ini dibuktikan dengan tiga Festival pariwisata di Riau yang masuk dalam kalender pariwisata nasional. Yaitu Pacu Jalur, Bono Surfing, Festival Bakar Tongkang. Dari tiga iven di Riau ini Pacu jalur menempati urutan teratas masuk dalam Wonderful Indonesia.

Berkaitan dengan Festival Pacu Jalur, mendapatkan penghargaan Pesona Indonesia pada tahun 2019 dengan acuan penilain berbasis 3A (atraksi, aksesibilitas, amenitas) dan 3S (size, sustainable, spread)dengan kunjungan200.000 pengunjung (riau.go.id). Penghargaan ini tidak terlepas dari peran generasi milinial pada proses promosi secara digital. Promosi yang dilakukan oleh Pencinta Festival Pacu Jalur Kuantan Singingi, di promosikan melalui media sosial Facebook dalam memberikan informasi dan promosi (https://web.facebook.com/groups/ipjks), IPJKS CHANNEL youtube, dan (https://www.instagram.com/pacujaluronline/).

Proses pemberdayaan masyarakat ini dilakukan oleh Pemerintah Daerah Kabupaten Kuantan Singingi ini merupakan bentuk promosi festival pacu jalur.Pemberdayaan generasi milinial ini menarik bagi masyarakat(Mandiling et al., 2019)karena respon lebih cepat oleh kalangan generasi milenial dalam peralihan teknologi dalam dunia wisata(Agoes, 2020). Pemerintah Kabupaten Kuantan Singingi membentuk forum media social ini dalam rangka melakukan pemberdayaan masyarakat. Ini menurut(Narulita, 2018)Pemberdayaan selalu tertuju pada terjadinya peningkatan kesadaran dan pengembangan potensi atau kemampuan untuk membuat sesuatu menjadi berbeda dan untuk membuat tindakan perubahan yang signifikan kearah peningkatan mutu dan taraf kehidupan yang lebih baik.

Berkaitan dengan prestasi dan proses pemberdayaan generasi milienial pada festival pacu jalur Kabupaten Kuantan Singingi, maka peneliti tertarik Pemberdayaan Generasi Milenial Tourisme Dalam Festival Pacu Jalur Tradisional Kabupaten Kuantan Singingi. 


\section{METODE}

Penelitian ini mengunakan pendekatan kualitatif dengan prosedur menghasilkan data deskriptif berupa kata-kata tertulis atau lisan orang-oran dan perilaku yang dapat diamati, Bogdan dan Taylor dalam (Moleong, 2011). Denganciri-ciri dilaksanakan dengan latar alami, karena mengunakan data langsung dari peristiwa yang besifat deskriptif dengan lebih memperhatikan proses dari pada hasil atau produk semata. Penelitian kualitatifini lebih mengunakan analisis data yang cendrung dengan car induktif dan mengamati dan hasil yang mementingkan makna. Penentuan subjek penelitian dengan purposive sampling karena merupakan pilihan penelitian tentang aspek apa dan siapa yang dijadikan focus pada saat sistuasi tertentu dan secara terus-menerus sepanjang penelitian.

Objek penelitian ini adalah sasaran ilmiah untuk mendapatkan data dan guna tertentu dengan focus kepada pemberdayaan generasi milenial yang dilakukan oleh pemerintah Kabupaten Kuantan Singingi dalam festival Pacu Jalur Kabupaten Kuantan Singingi. Sedangkan Setting penelitian dilaksnakan di DinasPariwisata dan Media Sosial Festival Pacu Jalur Kabupaten Kuantan Singingi yang sedang berkemabang dikalangan pencinta dan generasi milinial pengguna media sosial.

Berdasarkan pendekatan penelitian maka Teknik pengumpulan data penelitian ini yang bersumber dari dokumen, observasi dan wawancara, dokumen merupakan hasil publikasi dari pemerintah dan media cetak.dan media sosial yang berkaitan dengan festivasl Pacu Jalur Kabupaten Kuantan Singingi. Sedangkan proses observasi dilakukan dengan penijauan langsung ke Kabupaten Kuantan Singingi terutama Dinas Pariwisata dan pengiat festival pacu jalur Kabupaten Kuantan Singingi dan pengamatan proses interaksi melalui media sosial festival Pacu Jalur Kabupaten Kuantan Singingi. Wawancara dilakukan dengan pihak pemerintah dan pengiat media sosial Festival Pacu Jalur Kabupaten Kuantan Singingi baik secara langsung maupun tidak langsung.

Instrumen penelitian ini merupakan peneliti sendiri dengan fokus pada isntrumen penelitian sederahan yang diharapkan dapat melengkapi data dan membandingkan dengan data yang diperoleh melalui observasi dan wawancara. Sedangkan analisis data mengadopsi model interaktif(Miller Huberman, 2014)dengan melakukan reduksi data dengan proses pemilihan, pemusatan, perahtian pada penyederhanaan, abstraksi dan transformasi data kasar yang diperoleh dilapangan. Selanjutnya dilakukan penyajian data dengan laporan sistematis yang mudah dibaca tadi pahami baik secara keseluruhan maupun bagian-bagian dalam konteks pernyataan. Selanjutnya dilakukan pengambilan kesimpulan yang diverifikasi atau pengulangan sebagai pemikiran kedua yang timbul melintas waktu menulis. Untuk keabsahan data dilakukan dengan proses triangulasi dengan melakukan pemeriksaaan keabsahan data yang memanfaatkan sesuatu yang lain diluar data untuk keperluan pengecekan atau pembanding terhadap data-data tersebut.

\section{HASIL DAN PEMBAHASAN}

\section{Pemberdayaan Generasi Milenial Dalam Festival Pacu Jalur Kabupaten Kuantan Singingi}

Pemberdayaan masyarakat dalam konteks pembangunan semakin popular dalam menigkatkan partisipasi masyarakat. Pemberdayaan menekankan pada bagaimana membuat masyararakat mampu membangun dirinya dan memperbaiki kehidupan sendiri (Slamet, 2003). Istilah mampu dalam penelitian ini diartikan berkaitan dengan berdaya, paham, termotivasi, memiliki kesempatan, melihat, dan memanfaatkan peluang, berenergi, mampu bekerjasama, tahu sebagai alternatif, mampu mengambil keputusan, berani mengambil resiko, mampu mencari dan menagkap informasi, serta mampu bertindak sesuai inisiatif dalam mempromosikan Festival Pacu Jalur di Kabupaten Kuantan Singingi. Prinsip pemberdayaan yang utama dalam penelitian ini dilihat dari Pendekatan dari bawah (bottom up approach) 
pada kondisi ini pengelolaan dan para stakeholders setuju pada tujuan yang ingin dicapai untuk kemudian mengembangkan gagasan dan beberapa kegiatan setahap demi setahap untuk mencapai tujuan yang telah dirumuskan dalam Festival Pacu Jalur Kabupaten Kuantan Singingi sebelumnya.

Pemberdayaan dilihat dari partisipasi (participation) dimana setiap actor yang terlibat memiliki kekuasaan dalam setiap fase perencanaan promosi Festival Pacu Jalur Kabupaten Kuantan Singingi dan pengelolaan media sosial yang telah disepakati untuk memberikan informasi promosi Festival Pacu Jalur Kabupaten Kuantan Singingi. Selanjutnya dalam pemberdayaan keberlanjutan dilihat dari proses pengembangan media informasi dengan media social sehingga program informasi kepada pengguna media sosial oleh genererasi milenial diterima secara sosial dan ekonomi oleh para generasi milenial dalam kegiatan Festival Pacu Jalur Kabupaten Kuantan Singingi. Keterpaduan oleh peneliti dilihat dari aspek kebijakan dilihat dari tingkat nasional, regional dan lokal. Keuntungan dalam pemberdayaan ini dilihat dari kegiatan penyampaian informasi Festival Pacu Jalur Kabupaten Kuantan Singingi.

Masyarakat yang dimaksud dalam penelitian ini merupakan para generasi milenial yang aktif dalam proses penyebaran informasi Festival Pacu Jalur Kabupaten Kuantan Singingi. Berikaitan dengan penjelasan pemberdayaan adopsi dari pendapat Drijver dan Sajise ((Mamonto et al., 2017). Hasil penelitian menunjukkan bahwa dalam proses promosi dan informasi wisata dalam Dalam Festival Pacu Jalur Kabupaten Kuantan Singingi pemerintah Kabupaten Kuantan singing memberikan ruang kepada generasi milenial pengiat wisata pacu jalur dalam menyampaikan informasi dapat dilihat dari hasil wawancara dengan Ketua Kuansing Bacarito dalam informasi Festival Pacu Jalur bahwa'Pemberdayaan dilakukan dengan memanfaatkan media online dilakukan agar penyampaian informasi Festival Pacu Jalur dimulai dari motivasi generasi milenial dan didukung oleh pemerintah daerah melalui dinas pariwisata".

Lahirnya komunitas Informasi Pacu Jalur bahkan diberikan apresiasi oleh Bupati Kuantan Singingi karena lahir dari anak-anak muda kreatif yang didasri oleh keperluan informasi yang cepat tentang dalam Festival Pacu Jalur Kabupaten Kuantan Singingi.Ketua IPJKS bapakJunedi, SE menjelaskan ‘ bahwa IPJKS sudah melakukan live streaming dan adanya aplikasi tambahan di Google Play store untuk informasi pacu jalur disetiap event kecamatan dan nasional.

2. Partisipasi ini lahir dari adanya kemampuan generasi milenial dalam penguasan teknologiin formasi media sosial yang dapat bermanfaat dalam menyampaikan informasi Festival Pacu Jalur Kabupaten Kuantan Singingi.

Selain itu tujuan generasi milenial ini untuk memupuk kecintaan pada Festival Pacu Jalur Kabupaten Kuantan Singingi.Berdasarkan penjelasan secara deskripsi dari inform-informan dan sumber media social penelitian ini menemukan bahwa:

a. Memiliki kesempatan, melihat dan memanfaatkan peluang

Memiliki kesempatan dalam menunjang festival pacu jalur sebagai pendukung promosi dan peningkatan minat pengunjung dan proses cepat tanpa batas dengan penggunaan media sosial yang dapat dilihat secara lokal, regional, nasional dan international kepada seluruh pengguna media social terutama para generasi milenial. Karena dengan kesempatan menunjang festival pacu jalur ini suatu kebanggaan bagi genarasi milenial dan pengobat rindu pagi masyrakat yang bersala dari Kabupaten Kuantan Singingi dengan kemampuan yang dimiliki para komunitas festival pacu jalur jadi menarik bagi wisatwan dan juri penilai Pesona Indonesia dan menghasilkankemenangan dalam promosi tersbut. Untuk melihat dan memanfaatkan peluang yang ada. Kemampuan yang dimiliki dalam menunjang festival pacu jalur kemudian dimanfaatkan sebagai kesempatan yang ada dengan menuangkan ide-ide serta kreatifitas masyarakat melalui kemampuan yang masyarakat miliki dalam memberikan informasi pacu jalur. 
b. Mampu bekerjasama

Lahirnya komunitas media social generasi milenial mendorong insiatif Kerjasama pemerintah daerah dalam mempromisikan dan menginformasikan festival Pacu Jalur yang mendunia dalam rangka menarik dan memenangkan Pesona Indonesia. Mampu bekerjasama adalah bagaimana generasi milenial yang diberdayakan oleh pemerintah mampu menunjang sector pariwisata festival pacu jalur dengan kemampuan dan kreatifitas generasi milenial dengan tujuan agar mendapatkan keuntungan bagi sector pariwisata dan keuntungan bagi masyarakat sendiri yaitu dengan mendukung festival pacu jalur dapat meningkatkan perekonomian melalui perlombaan media sosial Instagram dan youtube generasi milenial yang perlu pengawasan dan binaan oleh pemerintah melalui Dinas Pariwisata. Agar kegiatan dalam menunjang sector pariwisata festival pacu jalur dapat dinformasikan terlaksanakan dan berjalan dengan baik. dan generasi milenial mampu dalam bekerjasama, pemerintah harus memperhatikan kebutuhan dari generasi millennial dalam meymapikan informasi dalam media socialnya yang sebaiknya harus menimbulkan inovasi-inovasi baru dan dapat menciptakan ide-ide yang unik dan tentunya mendatangkan keuntungan bagi keduanya. Yaitu bagi genarasi milenial dan tempat wisata festival pacu jalur. Dalam menjalin kerjasama yang baik pemerintah perlu mengadakan event-event yang dapat membangun kekompakan bagi pemerintah dan genarasi milenial misalnya mengadakan lomba konten media social dalam menyampaikan infromasi pacu jalur pada event nasional. Masyarakat dan pemerintah juga harus memelihara Budaya dan tetap menjaga keunikan dari festival pacu jalur, seperti proses perlombaan dan nilai-nilai tradisi budaya yang ada dalam daya tarik tersendiri yang masih sangat kental dengan budaya tradisional serta kebiasaan-kebiasaan kultural dari festival pacujalur yang perlu ditonjolkan dan dijadikan daya tarik bagi pengunjung untuk dating festival pacu jalur Kabupaten Kuantan Singingi. karna salah satu factor untuk memperkenalkan dan menjadikan daya destinasi dan pertunjukkan pacu jalur.

\section{c. Mampu mencari dan menagkap informasi}

Generasi Milenial yang mampu mencari informasi serta menagkap informasi yang baik dengan cepat dan lengkap. Karena dengan informasi generasi milenial dapat membuat konten dalam mendukung festival pacu jalur yang menjadi daya tarik pengunjung untuk ikut menyaksiakan dan berpatisipasi dalam menyebarkan informasi tentang Festival Pacu Jalur Kuantan Singingi. Tanpa adanya informasi yang jelas, masyarakat dan pengunjung tidak akan mengetahui kelebihan dan keunikan apa yang dalam festival pacu jalur Kabupaten Kuantan Singingi, tidak akan memaham ini lai jual dari kearifan lokal yang ada, serta karakteristik pengunjung dari luar daerah..

Masyarakat dan Pemerintah Daerah harus mampu mencari informasi dan menangkap informasi yang nantinya apa yang akan dibutuhkan oleh pengunjung, berakitan dengan event-event yang akan dilaksanakan setiap tahunnya yang mendorong banyaknya kedatangan pengunjung, informasi yang disediakan harus manpu menampilkan ada event apa saja yang akan di laksanakan di saat Festival Pacu Jalur. Agar Generasi Melenial yang nantinya menyampaikan informasi pacu jalur dapat menyediakan kelebihan dan keunikan apa saja yang diingini pengunjung. Dan juga pada era global ini yang semuanya sudah terbilang canggih, masyarakat harus mendapatkan dan mampu menggunakan kecanggihan dari zaman yang sudah serba canggih ini yaitu dengan internet. Karena internet adalah sumber informasi yang cepat dan baik dan dengan internet juga pemerintah dan masyarakat akan dengan mudah mempromosikan dan memperkenalkan Festival Pacu Jalur dan destinasi pendukungnya. 


\section{Faktor-Faktor yang Mempengaruhi Pemberdayaan Generasi Milenial Dalam Festival Pacu Jalur Kabupaten Kuantan Singingi.}

Kegiatan Penyampaian informasi pacu jalur melalui media sosial yang dilakukan generasi milenial Kabupaten Kuantan Singingi karena adanya rasa kecintaan generasi milenial terhadap Festival Pacu Jalur Tradisional Kabupaten Kuantan Singingi hal ini terlihat dari media-media sosial yang dibuatdan partisipasi yang ada pada media social tidak ada menyampaikan hal negative tentang Pacu Jalur Kabupaten Kuantan Singingi. Faktor berikutnya rasa kecintaan para masayarakat asal Kabupaten Kuantan Singingi dan menanamkan rasa bangga kepada keturunannya akan Festival Pacu Jalur Tradisonal merupakan kembanggan para orang tua dan penerusnya. Temuan penelitian selanjutnya media yang digunakan dalam menyebar luaskan informasi Festival Pacu Jalur melalui media sosial Facebook, Instagram, Youtube yang popular digunakan generasi milenial. Selain itu factor keterlibatan mahasiswa yang melakukan kegiatan pengabdian di Kabupaten Kuantan Singingi yang juga ikut berpartsipasi.

\section{KESIMPULAN}

Berdasarakan hasil penelitian yang telah dijabarkan maka peneliti dapat meyimpulkan bahwa Peran generasi milenial dapat mempengaruhi peneyebaran informasi Pacu Jalur Kabupaten Kuantan Singingi. Hasil penelitian menunjukkan bahwa pemberdayaan generasi milenial dilakukan dengan pendekatan media sosial oleh pemerintah Kabupaten Kuantan Singingi. Selain itu faktor yang mempengaruhi adalah rasa kecintaan generasi milenial terhadap Festival Pacu Jalur Tradisional Kabupaten Kuantan Singingi. Faktor berikutnya rasa kecintaan para masayarakat asal Kabupaten Kuantan Singingi dan menanamkan rasa bangga kepada keturunannya akan Festival Pacu Jalur Tradisonal. Temuan penelitian selanjutnya media yang digunakan dalam menyebarluaskan informasi Festival Pacu Jalur melalui media sosial Facebook, Instagram, Youtube yang popular digunakan generasi milenial. Selain itu factor keterlibatan mahasiswa yang melakukan kegiatan pengabdian di Kabupaten Kuantan Singingi yang juga ikut berpartsipasi. Dari hasil penelitian ini dapat menjadi rujukan bagi peniliti berikutnya tentang pemberdayaan masyarakat pada Festival pariwisata lainnya.

\section{SARAN}

Pemerintah daerah harus terus melakukan pembinaan generasi milenial dan memberikan reward kepada generasi milenial dalam proses penyampaian informasi pacu jalur Kabupaten Kuantan Singingi, selain itu juga menambah daya tarik lainnya bagi pengunjung serta sarana prasarana pendukung pemberdayaan genera similenial melalui media social dalam menyampaikain formasi Pacu Jalur Kabupaten Kuantan Singingi. 


\section{DAFTAR PUSTAKA}

[1] Agoes, A. (2020). Peran Lembaga Pendidikan Pariwisata Di Era Digital Tourism. Tourism Scientific Journal, 5(2), 183-195.

[2] Blunt, P. (1995). Cultural relativism, 'good' governance and sustainable human development. Public Administration and Development, 15(1), 1-9. https://doi.org/10.1002/pad.4230150102

[3] Khandakar Qudrat-I Elahi. (2009). UNDP on good governance. International Journal of Social Economics, 36(12), 1167-1180.

[4] Mamonto, N., Gosal, T. A. M. R., \& Singkoh, F. (2017). Pemberdayaan Masyarakat Dalam Menunjang Sektor Pariwisata Sebagai Pendukung Perekonomian. Jurnal Eksekutif, 1(1), 1-9.

[5] Mandiling, I. H., Wardi, F., Kusumawadi, M. A., Ulfaturrahman, L., \& Zohri, T. (2019). Pemberdayaan Generasi Milenial Desa Ranggata Melalui Budidaya Puyuh Berbasis Edupreneur. Jurnal Pendidikan Dan Pengabdian, 2(2), 317-320.https://doi.org/10.1017/CBO9781107415324.004

[6] Miles, M. B., Huberman, A. M., \& Saldana, J. (2014). Qualitative data analysis: A methods sourcebook

[7] Moeleong, L. J. 2011. MetodologiPenelitianKualitatifedisirevisi. Bandung: RemajaRosdakarya.

[8] Narulita, M. D. (2018). Pemberdayaan Masyarakat Dalam Mendukung Pengembangan Desa Wisata Cihideung, Kabupaten Bandung Barat. Tourism Scientific Journal, 3(1), 58. https://doi.org/10.32659/tsj.v3i1.35

[9] Slamet, M. (2003). Pemberdayaanmasyarakat. DalamMembentuk Pola PerilakuManusia Pembangunan. Penyunting: Ida Yustina dan AjatSudrajat, 45-48.

[10] https://www.riau.go.id/home/content/2017/08/24/6818-kunjungan-wisatawan-ke-festival-pacu-jalurmencapai-200000

[11] https://web.facebook.com/groups/ipjks),

[12] https://www.instagram.com/pacujaluronline/ . 